\title{
ODREĐIVANJE TIJEKA OSLOBAĐANJA TOPLINE HIDRATACIJE U BETONU
}

\section{Ivan Gabrijel}

Sveučilište u Zagrebu, Građevinski fakultet Zagreb, dr.sc. Jure Barbalić

Sveučilište u Zagrebu, Građevinski fakultet Zagreb, univ.bacc.građ., student

\begin{abstract}
Sažetak: Nepovoljna distribucija temperature u betonskim elementima može dovesti do nastanka pukotina. Sprječavanje nastanka pukotina provodi se planiranjem tehnologije izvođenja. Velika pomoć pritom su proračuni raspodjele temperature. Proračun temperaturnih promjena u betonu mora uzeti u obzir međudjelovanje betonskih elemenata s okolišem, uz istovremeno generiranje topline u betonu zbog hidratacije cementa. Budući da su uvjeti u okolišu i toplina koja se oslobađa promjenjivi u vremenu, predviđanje distribucije temperature postaje složen problem. Tijek oslobađanja topline hidratacije u betonu predstavlja vrlo bitan parametar, jer služi za proračun temperaturnih promjena, a također je i pokazatelj napretka hidratacije cementa. $\mathrm{U}$ ovom radu prikazan je matematički model kojim se opisuje razvoj topline hidratacije tijekom vremena. Provedena su laboratorijska ispitivanja oslobađanja topline hidratacije u betonu diferencijskim kalorimetrom. Analize su provedene na 6 mješavina betona izrađenih s različitim vodocementnim (v/c) omjerima i dvije vrste cementa.
\end{abstract}

Ključne riječi: toplina, hidratacija, cement, pukotine

\section{DETERMINATION OF HEAT OF HYDRATION FLOW IN CONCRETE}

\begin{abstract}
Adverse temperature distribution in concrete elements can lead to cracking. Prevention of cracking is made through planning of construction technology. Great help during planning are temperature distribution calculations. Calculation of temperature changes in concrete must take into consideration interaction of concrete elements with environment and simultaneously heat generation in concrete from cement hydration. Because environmental conditions and heat liberation are both time dependent prediction of temperature distribution becomes complex problem. Hydration heat liberation in concrete is a very important parameter because it serves for calculation of temperature changes and is also an indicator of progress of cement hydration. In this paper a mathematical model is presented which can describe hydration heat evolution in time. Laboratory tests of hydration heat liberation in concrete are made using differential calorimeter. Analysis is made on 6 concrete mixtures made with different water-cement (w/c) ratio and two cement types.
\end{abstract}

Key words: heat, hydration, cement, cracks 


\section{Uvod}

U prvih nekoliko dana nakon betoniranja, za beton se koristi termin "mladi beton“. U mladom betonu dolazi do velikih kemijskih i fizikalnih promjena strukture zbog kojih se značajno mijenjaju njegova svojstva. Kada se izvrši većina promjena u strukturi, tada se i svojstva betona vrlo malo mijenjaju i kažemo da imamo potpuno očvrsnuli beton. U praksi smatramo da imamo potpuno očvrsnuli beton kod starosti od 28 dana.

Prilikom izgradnje strukture u prvim danima hidratacije cementa, u betonu se javljaju naprezanja koja ne moraju biti povezana s opterećenjem koja beton preuzima, nego su posljedica deformacija koja nastaju zbog kemijskog skupljanja, skupljanja zbog izlaska vode iz pora i promjena temperature [1].

Deformacije nastale zbog nejednolike distribucije temperature mogu dovesti do nastanka pukotina ako razina naprezanja dostigne čvrstoću materijala i takva pojava je tipična za masivne betonske elemente koji se izvode prilikom izgradnje brana ili temelja velikih dimenzija. Nastanak pukotina zbog djelovanja naprezanja izazvanih nejednolikom distribucijom temperature može se smanjiti ili spriječiti ako se poduzmu odgovarajuće mjere prilikom projektiranja tehnologije izvedbe betonskih konstrukcija, odnosno provedbom proračuna temperaturnih promjena. Proračun temperaturnih promjena obuhvaća analizu međuovisnosti između, npr., dimenzija betonskih elemenata, rasporeda ugradnje, početne temperature betona, količine cementa u betonu i temperature okoliša $\mathrm{s}$ jedne strane, te distribucije temperature u betonskim elementima s druge strane. Ako nastala distribucija temperature ne izaziva naprezanja veća od čvrstoće betona, smatra se da neće doći do pojave pukotina [2].

Za provedbu proračuna promjena temperature potrebno je prikupiti ulazne parametre, odnosno podatke 0 svojstvima betona, mogućim načinima izvedbe konstrukcije, vrstama oplata, prosječnim temperaturama okoliša na mjestu izgradnje i sl. Osnovni matematički izraz kojim se određuje distribucija temperature u čvrstom tijelu koje sadrži unutarnji izvor topline razvio je Fourier [3].Ako je materijal gustoće $\rho$ i specifičnog toplinskog kapaciteta $c$ homogen i izotropan, vrijedi izraz:

$$
\lambda\left(\frac{\partial^{2} T}{\partial x^{2}}+\frac{\partial^{2} T}{\partial y^{2}}+\frac{\partial^{2} T}{\partial z^{2}}\right)+q=\rho \cdot c \cdot \frac{\partial T}{\partial t}
$$

gdje je $\lambda$ toplinska provodljivost, $T$ temperatura i $x, y, z$ su koordinate u Kartezijevom koordinatnom sustavu, $t$ vrijeme i $q$ toplina generirana u unutrašnjosti diferencijalnog elementa u jedinici vremena. $U$ slučaju proračuna temperaturnih promjena u betonu, prirast generirane količine topline $q$ povezan je s porastom temperature kao posljedicom hidratacije cementa. Metode koje kvantificiraju toplinu hidratacije cementa tvore osnovnu komponentu svih načina i metoda rješavanja gore predstavljenog matematičkog problema [2]. Pritom se postavlja pitanje: „Na koji način odrediti tijek oslobađanja topline hidratacije, a da se rezultati mogu primijeniti za provedbu proračuna temperatura u betonu?"

\section{Oslobađanje topline hidratacije cementa}

\subsection{Hidratacija cementa}

Brzina kojom se odvijaju reakcije hidratacije blisko su povezane s brzinom kojom se oslobađa toplina hidratacije. Poredak pojedinih čistih mineralnih faza portland-cementnog klinkera prema njihovoj reaktivnosti uobičajeno je:

$$
\mathrm{C}_{3} \mathrm{~A}>\mathrm{C}_{3} \mathrm{~S}>\mathrm{C}_{4} \mathrm{AF}>\mathrm{C}_{2} \mathrm{~S}
$$

gdje su $\mathrm{C}_{3} \mathrm{~A}$ - trikalcij aluminat, $\mathrm{C}_{3} \mathrm{~S}$ - trikalcij silikat, $\mathrm{C}_{4} \mathrm{AF}$ - tetrakalcij aluminat ferit i $\mathrm{C}_{2} \mathrm{~S}$ - dikalcij silikat.

Reaktivnost dvaju cemenata sličnih kemijskih i mineraloških sastava može biti bitno različita, jer utjecaj na njihovu reaktivnost s vodom ovisi o uvjetima pečenja i brzini hlađenja klinkera $[4,5]$. Ti procesi uvjetuju raspodjelu mineralnih faza u klinkeru, veličinu njihovih kristala, koncentraciju defekata u kristalima itd. Drugi razlozi promjene 
brzine reakcije funkcija su: kemijski sastav cementa, finoća mliva cementa, vodo-cementni omjer, temperatura na kojoj se odvija reakcija, prisutnost dodataka itd. Ovi parametri određuju oblik krivulje oslobađanja topline hidratacije.

$\mathrm{Na}$ temelju poznavanja kemijskog sastava cementa, odnosno mineraloškog sastava cementa, može se odrediti samo ukupna količina topline hidratacije koja će se osloboditi ako hidratizira sav cement. Utjecaj kemijskog sastava cementa može se uvidjeti proučavanjem brzine hidratacije različith minerala te njihovim individualnim doprinosima ukupnoj toplini hidratacije cementa (tablica 1).

Tablica 1 - Toplina hidratacije pojedinačnih konstituenata portland cementa

\begin{tabular}{|l|c|c|c|c|}
\hline \multirow{2}{*}{ Konstituent } & \multicolumn{4}{|c|}{ Toplina hidratacije [J/g] } \\
\cline { 2 - 5 } & Mindess i Young [5] & Taylor [6] & Bogue [4] & Kishi i Maekawa [7] \\
\hline $\mathrm{C}_{3} \mathrm{~S}$ & 490 & 500 & 500 & 502 \\
\hline $\mathrm{C}_{2} \mathrm{~S}$ & 225 & 250 & 260 & 260 \\
\hline $\mathrm{C}_{3} \mathrm{~A}$ & 1170 & 1340 & 866 & 865 \\
\hline $\mathrm{C}_{4} \mathrm{AF}$ & 380 & 420 & 420 & 419 \\
\hline Slobodni CaO & - & 1150 & 1168 & - \\
\hline $\mathrm{MgO}$ & - & 840 & 850 & - \\
\hline
\end{tabular}

Težnja za smanjenjem emisija $\mathrm{CO}_{2}$ prilikom proizvodnje portland cementa dovela je do proizvodnje miješanih cemenata. Miješani cementi nastaju zamjenom dijela portland cementnog klinkera određenim dijelom mineralnog dodatka koji aktivno sudjeluje u procesu hidratacije. Kinetika hidratacije miješanih cemenata razlikuje se od kinetike hidratacije portland cementa pa je predviđanje tijeka oslobađanja topline hidratacije cementa složenije.

Metalurški cement se proizvodi zajedničkim mljevenjem portland cementnog klinkera i granulirane zgure visokih peći (u nastavku zgura), ali se u praksi upotrebljava i naknadno miješani samljeveni klinker i zgura [8]. Zgura visokih peći smanjuje brzinu oslobađanja topline hidratacije, ali ukupna toplina hidratacije granulirane zgure je veća ili jednaka nego kod običnog portland cementa $[7,8]$.

\subsection{Modeliranje tijeka oslobađanja topline}

Oslobađanje topline hidratacije portland cementa može se opisati troparametarskim eksponencijalnim modelom (jednadžba 3) [9]:

$$
Q(t)=Q_{\infty} \cdot e^{\left(-\frac{\tau}{t}\right)^{\beta}}
$$

gdje je $Q(t)$ toplina hidratacije koja će se osloboditi do vremena $t, Q_{\infty}$ je ukupna toplina hidratacije koja će se osloboditi do kraja procesa hidratacije cementa, $\tau$ je vremenski parametar, a $\beta$ koeficijent zakrivljenosti krivulje. Povezanost između prirasta generirane količine topline $q$ i oslobođene topline hidratacije $Q(t)$ prikazana je jednadžbom 4:

$$
q=\frac{d Q(t)}{d t}
$$

Iz jednadžbe 4 može se uočiti da je prirast generirane količine topline ekvivalentan brzini oslobađanja topline hidratacije. Prema tome, problem određivanja ulaznih parametara za proračun promjena temperatura u betonu svodi se na određivanje parametara modela $Q_{\infty}, \tau$ i $\beta$, odnosno na traženje matematičkog modela kojim se može opisati oslobađanje topline hidratacije. Parametri modela mogu se odrediti regresijskom analizom 
podataka o oslobađanju topline hidratacije tijekom vremena, dok se podaci o oslobađanju topline hidratacije cementa mogu odrediti eksperimentalnim ili numeričkim metodama [10].

\section{Eksperimentalni rad}

$\mathrm{U}$ ovom radu provedena su mjerenja topline hidratacije u betonu. Mjerenjima je proučavan utjecaj v/c omjera i tipa cementa na toplinu hidratacije. Mješavine su izrađene s tri različita v/c omjera $(0,4 ; 0,5$ i 0,65$)$ te dvije vrste cementa:

- CEM I 42,5 R, tj. čisti portland cement razreda čvrstoće $42,5 \mathrm{~s}$ brzim prirastom čvrstoće

- CEM III/B 32,5 N SR-LH, tj. metalurški cement koji se sastoji od 20-34 \% portland cementa i 66-80 $\%$ granulirane zgure, razreda je čvrstoće 32,5 i normalnog razvoja čvrstoće, sulfatno je otporan, a oslobođena toplina hidratacije zadovoljava uvjete za cement niske topline hidratacije.

Svojstva cemenata prikazana su u tablicama 2 i 3.

Tablica 2 - Kemijski sastav cemenata

\begin{tabular}{|c|c|c|}
\hline \multirow{2}{*}{ Sastojak } & CEM I 42,5 R & $\begin{array}{c}\text { CEM III/B 32,5 N } \\
\text { SR-LH }\end{array}$ \\
\cline { 2 - 3 } & udio (\%) & udio (\%) \\
\hline $\mathrm{CaO}$ & 64,36 & 48,37 \\
\hline $\mathrm{SiO}_{2}$ & 20,32 & 29,36 \\
\hline $\mathrm{Al}_{2} \mathrm{O}_{3}$ & 5,62 & 9,20 \\
\hline $\mathrm{Fe}_{2} \mathrm{O}_{3}$ & 3,08 & 1,74 \\
\hline $\mathrm{MgO}$ & 2,90 & 6,11 \\
\hline $\mathrm{SO}_{3}$ & 2,40 & 2,77 \\
\hline $\mathrm{K}_{2} \mathrm{O}$ & 1,03 & 0,57 \\
\hline $\mathrm{Na}_{2} \mathrm{O}$ & 0,42 & 0,29 \\
\hline $\mathrm{MnO}$ & 0,21 & 0,32 \\
\hline $\mathrm{Cl}$ & 0,007 & 0,071 \\
\hline Gubitak žarenjem & 1,1 & 1,23 \\
\hline
\end{tabular}

Tablica 3 - Fizikalna svojstva cemenata

\begin{tabular}{|l|c|c|}
\hline \multicolumn{1}{|c|}{ Svojstvo } & CEM I 42,5 R & $\begin{array}{c}\text { CEM III/B 32,5 N } \\
\text { SR-LH }\end{array}$ \\
\hline Specifična površina $\left(\mathrm{cm}^{2} / \mathrm{g}\right)$ & 3082,0 & 3900,0 \\
\hline Gustoća $\left(\mathrm{kg}_{\mathrm{d}} \mathrm{dm}^{3}\right)$ & 3,14 & 2,94 \\
\hline Standardna konzistencija $(\%)$ & 27,2 & 29,6 \\
\hline Početak vezanja (min) & 110 & 185 \\
\hline Kraj vezanja (min) & 140 & 220 \\
\hline
\end{tabular}

Za izradu mješavina korišten je drobljeni agregat, dolomit. Mješavine su izrađene s 3 frakcije agregata: 0-4 $\mathrm{mm}, 4-8 \mathrm{~mm}$ i 8-16 mm. Udio frakcija u mješavinama betona iznosio je $35,6 \%$ za frakciju 0-4 mm, 24,0 \% za frakciju 4-8 mm i 40,4 \% za frakciju 8-16 mm. 
Sastavi betona prikazani su u tablici 4 . U tablici 4 prikazani su i rezultati ispitivanja svojstava svježeg i očvrsnulog betona. Prije miješanja betona, sastojci su čuvani u laboratoriju na temperaturi od $20 \pm 2{ }^{\circ} \mathrm{C}$ u trajanju od 12 do 24 sata. Miješanje betona provedeno je u skladu s normom HRN EN 480-11:2007.

Tablica 4 - Sastavi betona na kojima su provedena ispitivanja

\begin{tabular}{|l|c|c|c|c|c|c|}
\hline \multirow{2}{*}{ Sastojak } & \multicolumn{7}{|c|}{ OZNAKA MJEŠAVINE } \\
\cline { 2 - 7 } & BCEMI-0.4 & BCEMI-0.5 & BCEMI-0.65 & BCEMIII-0.4 & BCEMIII-0.5 & BCEMIII-0.65 \\
\hline Cement (kg) & 475,0 & 380,0 & 292,3 & 475,0 & 380,0 & 292,3 \\
\hline Voda (kg) & 190,0 & 190,0 & 190,0 & 190,0 & 190,0 & 190,0 \\
\hline v/c omjer & 0,4 & 0,5 & 0,65 & 0,4 & 0,5 & 0,65 \\
\hline Agregat (kg) & 1793,4 & 1879,1 & 1958,1 & 1764,3 & 1855,9 & 1940,3 \\
\hline Svojstva & \multicolumn{7}{|c|}{} & 1,0 & 3,0 & 6,0 \\
\hline $\begin{array}{l}\text { Konzistencija } \\
\text { slijeganjem (cm) }\end{array}$ & 3,5 & 5,0 & 7,5 & 1,0 & 1,0 & 1,2 \\
\hline Količina pora (\%) & 1,8 & 1,1 & 1,4 & 2,2 & 2470 & 2460 \\
\hline Gustoća (kg/m³) & 2480 & 2490 & 2480 & 2450 & 2470 \\
\hline $\begin{array}{l}\text { Tlačna čvrstoća, 28 } \\
\text { dana (MPa) }\end{array}$ & 60,3 & 48,5 & 40,1 & 59,5 & 41,7 & 36,7 \\
\hline
\end{tabular}

\subsection{Ispitivanje topline hidratacije}

Mjerenje oslobađanja topline hidratacije na uzorcima betona provedeno je diferencijskim kalorimetrom ToniCAL, Model 7336, proizvođača ToniTechnik. Diferencijski kalorimetar je namijenjen kontinuiranom određivanju količine oslobođene topline hidratacije i mjerenju temperature u betonu tijekom cijelog hidratacijskog procesa. Kod primjene diferencijskog kalorimetra registrira se diferencijski signal između dviju serija termoparova koji pripadaju dvjema kalorimetrijskim jedinicama. Proces koji se proučava odvija se u jednoj kalorimetrijskoj jedinici, a druga služi kao „termička tara" i u njoj se nalazi referentni ili inertni sustav čime se uklanjaju smetnje izazvane okolinom. Temperatura inertnog uzorka održava se konstantnom, a temperatura uzorka betona se mijenja ovisno o oslobođenoj toplini hidratacije i izmjeni topline s okolišem. Tijelo kalorimetra u kojem se nalaze uzorci prikazano je na slici 1 a), a na slici 1 b) prikazan je cijeli mjerni sustav ToniCAL. 
a)

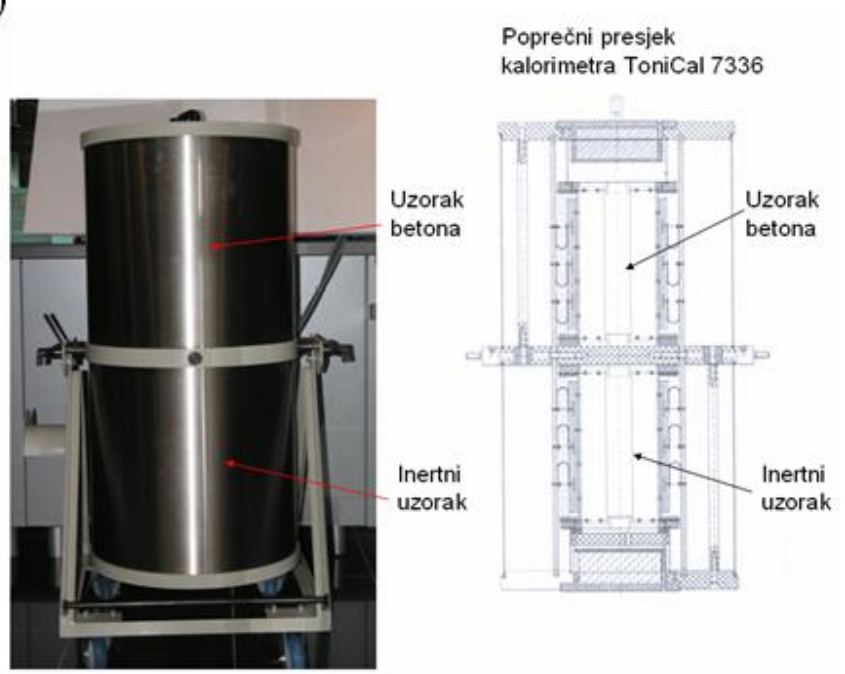

b)

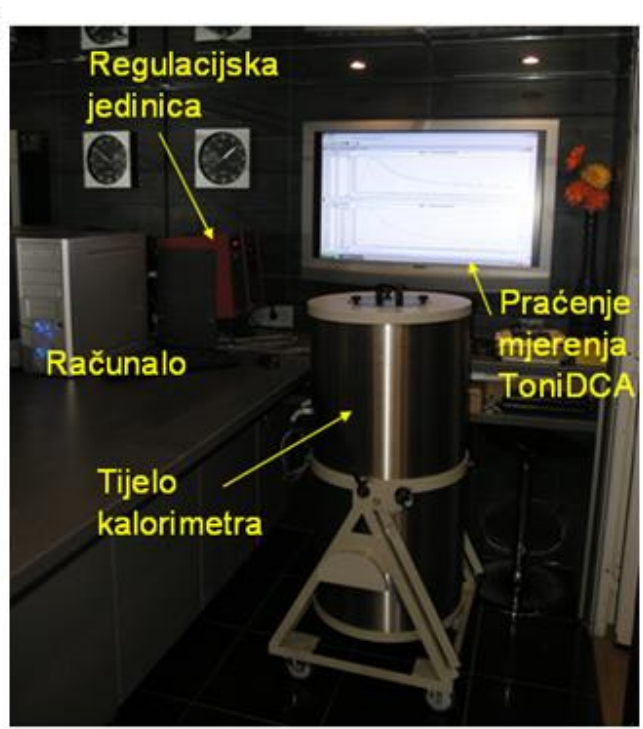

Slika 1 - a) tijelo kalorimetra ToniCal; b) mjerni sustav ToniCAL 7336

Tijekom mjerenja kalorimetar je smješten u prostoriju kontrolirane temperature u kojoj je održavana temperatura zraka od $(19 \pm 2)^{\circ} \mathrm{C}$. Uzorak betona na kojem se provode mjerenja je valjak dimenzija $\mathrm{h}=300 \mathrm{~mm}$, $d=150 \mathrm{~mm}$. Poslije miješanja betona uzorak se ugrađuje u čelični kalup i zbija na vibrostolu, nakon čega se postavlja u tijelo kalorimetra. Prosječno vrijeme proteklo od početka miješanja betona pa do početka mjerenja iznosi oko 20 minuta. Mjerena je brzina oslobađanja topline hidratacije, ukupna oslobođena toplina te temperatura uzorka. Mjerenje je trajalo sve dok brzina oslobađanja topline nije postala dovoljno mala, tj. dok proces hidratacije nije ušao u fazu reakcija kontroliranih difuzijom $[4,5]$.

\section{Analiza rezultata mjerenja}

Na slici 2 prikazan je tijek oslobađanja topline hidratacije u uzorcima izrađenim s portland cementom, a na slici 3 za uzorke izrađene s metalurškim cementom. Na slici 4 prikazana je brzina oslobađanja topline hidratacije u uzorcima izrađenim s portland cementom, a na slici 5 za uzorke izrađene s metalurškim cementom. Mjerenje topline hidratacije zaustavljeno je kada je brzina oslobađanja topline hidratacije postala manja od $1 \mathrm{~J} /(\mathrm{g} \bullet \mathrm{h})$, što odgovara starosti uzoraka između 72 i 96 sati.

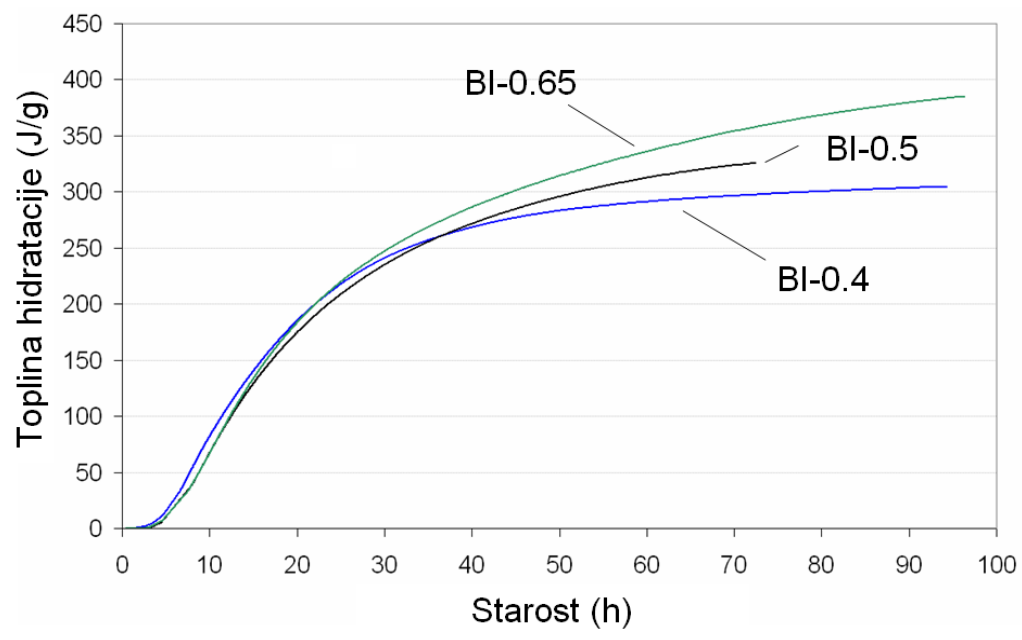


Slika 2 - Oslobađanje topline hidratacije u mješavinama izrađenim s portland cementom

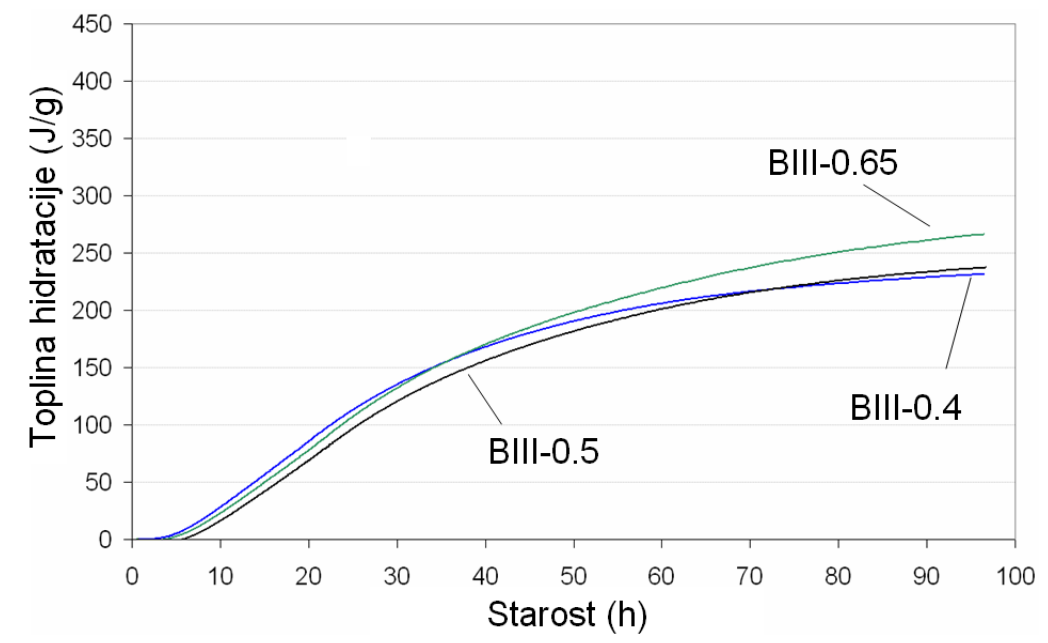

Slika 3 - Oslobađanje topline hidratacije u mješavinama izrađenim s metalurškim cementom

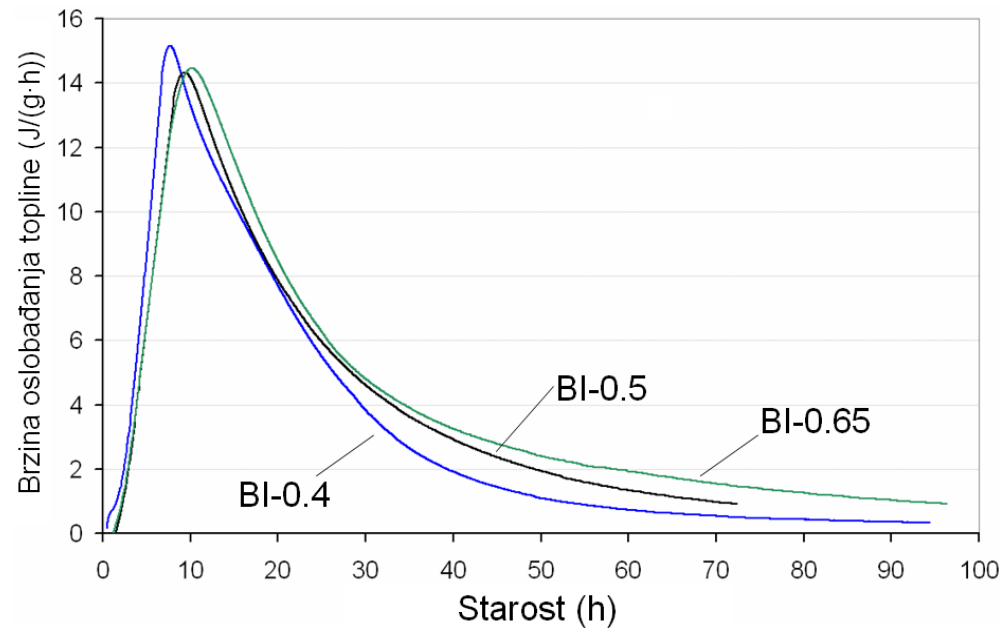

Slika 4 - Brzina oslobađanja topline hidratacije u mješavinama izrađenim s portland cementom 


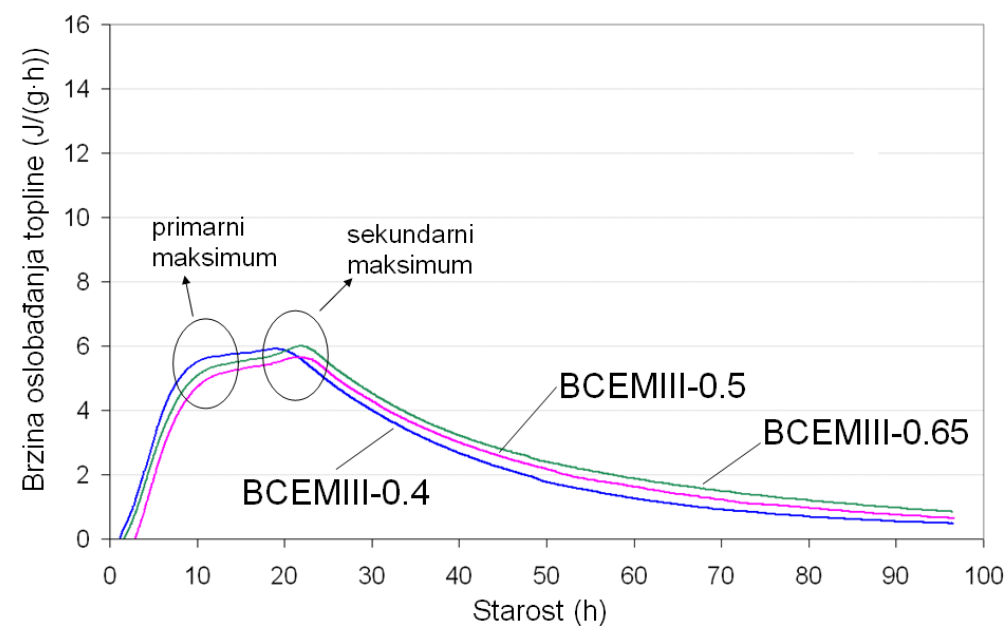

Slika 5 - Brzina oslobađanja topline hidratacije u mješavinama izrađenim s metalurškim cementom

Razvoj topline hidratacije u betonu opisan je troparametarskim eksponencijalnim modelom (jednadžba 3), a podatci o koeficijentima modela prikazani su u tablici 5.

Tablica 5 - Parametri eksponencijalnog modela koji opisuje razvoj topline hidratacije

\begin{tabular}{|c|c|c|c|c|}
\hline Cement & Oznaka mješavine & $Q_{\infty}(\mathrm{J} / \mathrm{g})$ & $\tau(\mathrm{h})$ & $\beta$ \\
\hline \multirow{3}{*}{ CEM I 42,5 R } & $\mathrm{BI}-0.4$ & 331 & 13,0 & 1,34 \\
\cline { 2 - 5 } & $\mathrm{BI}-0.5$ & 403 & 16,6 & 1,08 \\
\cline { 2 - 5 } & $\mathrm{BI}-0.65$ & 470 & 19,2 & 0,97 \\
\hline \multirow{3}{*}{ CEM III/B 32,5 N SR-LH } & $\mathrm{BIII-}-0.4$ & 292 & 23,4 & 1,09 \\
\cline { 2 - 5 } & $\mathrm{BIII-}-0.5$ & 326 & 28,8 & 1,03 \\
\cline { 2 - 5 } & $\mathrm{BIII-0.65}$ & 393 & 32,7 & 0,91 \\
\hline
\end{tabular}

Analizom rezultata mjerenja uočeno je sljedeće:

- Količina topline hidratacije koja se oslobodi manja je u mješavinama s manjim v/c omjerom (slika $2 \mathrm{i}$ 3 , tablica 5). Ova pojava pripisuje se tome što u cementnoj pasti većeg v/c omjera postoji više vode raspoložive za hidrataciju cementa, a također i više kapilarnog prostora u koji se mogu širiti čestice cementa [11].

- $\quad$ Utjecaj hidratacije zgure na oblik krivulje oslobađanja topline uočava se na slici 5. Zgura ne reagira u početnim satima hidratacije sve dok ne bude aktivirana kalcij hidroksidom nastalim hidratacijom portland cementa. Hidratacija zgure uzrokuje pojavu sekundarnog maksimuma na krivulji koja prikazuje brzinu oslobađanja topline hidratacije. Primarni maksimum pripisuje se hidrataciji portland cementa.

- Brzina oslobađanja topline hidratacije veća je u mješavinama izrađenim s portland cementom tijekom prvih 50 sati hidratacije. Nakon tog perioda brže se oslobađa toplina u mješavinama izrađenim $\mathrm{s}$ metalurškim cementom.

- $\quad \mathrm{Na}$ temelju parametra eksponencijalnog modela - ukupna toplina hidratacije $\left(Q_{\infty}\right)$ određene regresijskom analizom, uočava se da mješavine izrađene $s$ metalurškim cementom imaju manju ukupnu toplinu hidratacije (tablica 5).

- Koeficijent determinacije prilikom određivanja parametara eksponencijalnog modela u svim mješavinama veći je od 0,98 , što pokazuje da odabrani model može dobro opisati razvoj topline hidratacije i za portland cement i za metalurški cement. 
- Usporedbom brzine oslobađanja topline hidratacije dobivene eksperimentalno i derivacijom eksponencijalnog modela (jednadžba 4), uočava se da se najveća odstupanja pojavljuju u mješavinama izrađenim $s$ metalurškim cementom u blizini sekundarnog maksimuma (slika 6). Korištenjem složenijih modela može se točnije opisati brzina oslobađanja topline hidratacije, ali za proračun temperaturnih promjena u betonu upotreba troparametarskog modela je dovoljno točna.

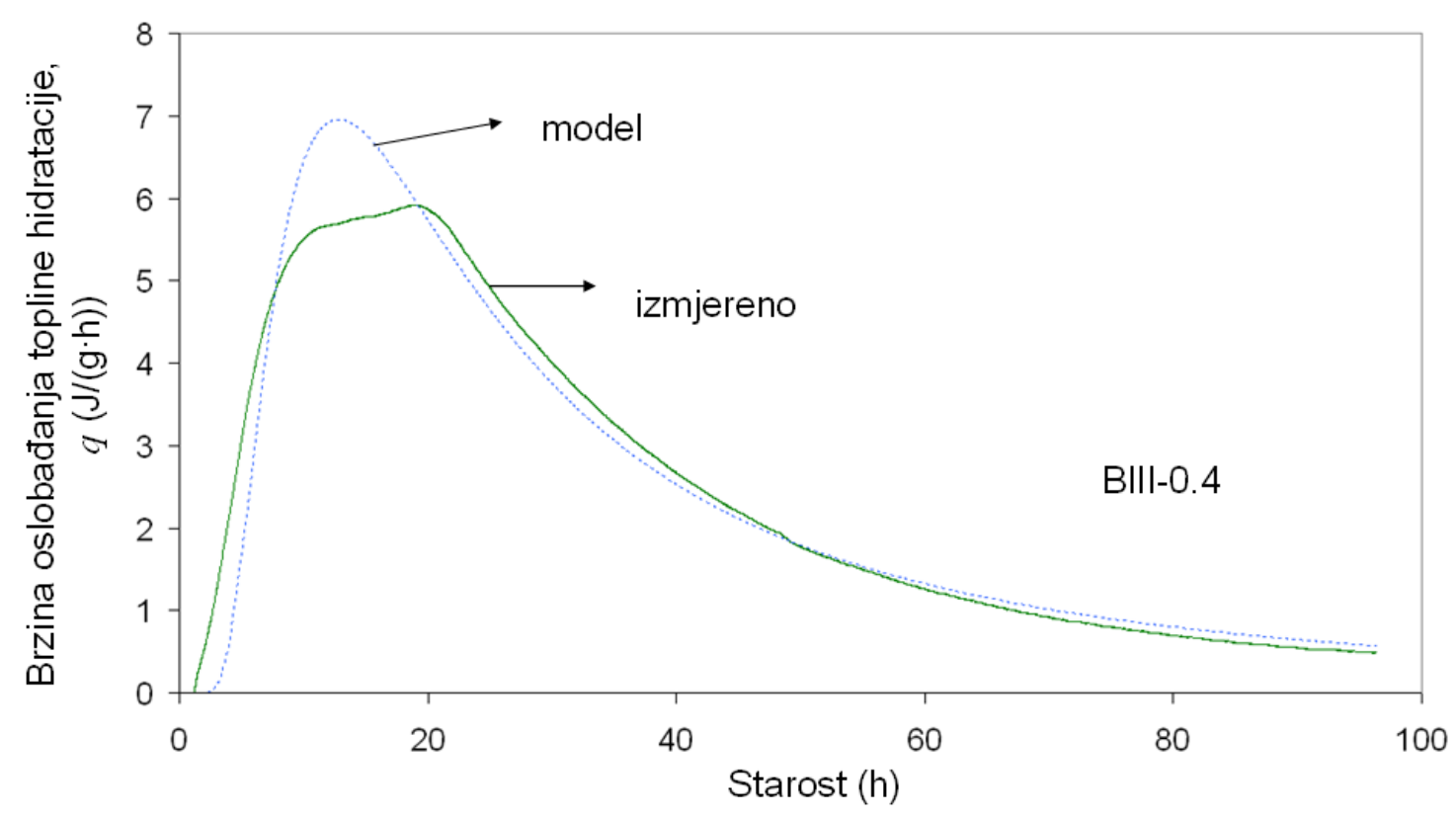

Slika 6 - Usporedba brzine oslobađanje topline hidratacije dobivene eksperimentalno i prve derivacije eksponencijalnog modela

\section{Zaključak}

Osnovni preduvjet za provedbu pouzdanog proračuna promjena temperatura u betonu je poznavanje tijeka oslobađanja topline hidratacije. U radu je prikazana metodologija koja povezuje mjerenje topline hidratacije u betonu i provođenje proračuna promjena temperatura. Troparametarskim eksponencijalnim modelom uspješno je opisano oslobađanje topline hidratacije u betonu u mješavinama izrađenim s portland cementom i metalurškim cementom i različitim vodocementnim omjerima. Usporedba eksperimentalno određene brzine oslobađanja topline hidratacije i prve derivacije troparametarskog eksponencijalnog modela pokazuje da model dobro opisuje brzinu oslobađanja topline hidratacije kod mješavina izrađenih s portland cementom, dok se kod mješavina izrađenih s metalurškim cementom pojavljuju veća odstupanja u području pojave sekundarnog maksimuma, tj. aktivacije zgure. Korištenjem složenijih modela može se točnije opisati brzina oslobađanja topline hidratacije za mješavine izrađene $s$ metalurškim cementom, ali za proračun temperaturnih promjena u betonu upotreba troparametarskog modela je dovoljno točna.

\section{Zahvala}

Opisano istraživanje je provedeno u sklopu znanstvenog projekta "Od nano do makrostrukture betona", 0820822161-2990, koji je financiran od strane Ministarstva znanosti obrazovanja i športa Republike Hrvatske.

\section{Literatura}


[1] Mehta, P. K.; Monteiro, P. J. M. 2006. Concrete - microstructure, properties and materials, third edition, The McGraw-Hill Companies Inc., New York

[2] Mikulić, D.; Milovanović, B.; Gabrijel, I. 2010. Simulacija toplinskog toka u betonu. // Građevinar: časopis Hrvatskog saveza građevinskih inženjera. 62 (10); 941-950.

[3] Galović, A. 2003. Termodinamika II, Fakultet Strojarstva i Brodogradnje, Sveučilišta u Zagrebu, Zagreb

[4] Đureković, A. 1996. Cement cementni kompozit i dodaci za beton, IGH Zagreb: Školska knjiga, Zagreb

[5] Mindess, S.; Young, J. F.; Darwin, D. 2002. Concrete, 2nd edition, Prentice-Hall inc., New Jersey

[6] Taylor, H. F. W. 1990. Cement chemistry, Academic Press, London

[7] Maekawa, K.; Chaube, R.; Kishi, T. 1999. Modelling of Concrete Performance - Hydration, Microstructure Formation and Mass Transport, Taylor \& Francis, New York

[8] ACl 233R-03. 2003. Slag Cement in Concrete and Mortar, American Concrete Institute

[9] Nielsen, C.V. 2007. Modeling the Heat Development of Concrete Associated with Cement Hydration, SP 241: Concrete Heat Development: Monitoring, Prediction \& Management, American Concrete Institute

[10] Barbalić, J. 2010. Tijek topline hidratacije u betonu, Završni rad, Sveučilište u Zagrebu, Građevinski fakultet

[11] Van Breugel, K. 1997. Simulation of Hydration and Formation of Structure in Hardening Cement-Based Materials, Delft Univ.Press, Delft 